At-Tijaroh : Jurnal Ilmu Manajemen dan Bisnis Islam

Volume 5 Nomor 1 Ed. Jan - Juni 2019 : Hal 83 - 97

p-ISSN : $2356-492 x$

e-ISSN : $2549-9270$

\title{
ANALISIS PROSPEK DAN STRATEGI PENGEMBANGAN USAHA JASA SYARIAH
}

\author{
Lia Vebrina Siregar ${ }^{1}$, Mustapa Kamal Rokan², Isnaini Harahap ${ }^{3}$ \\ 1,2,3 Universitas Islam Negeri Sumatera Utara \\ 1,2,3 Jl. Willem Iskandar Pasar V Medan, Sumatera Utara \\ 1 liavebrinasiregar@gmail.com \\ 2 mustafarokan@uinsu.ac.id \\ 3 Isnaini.harahap@uinsu.ac.id
}

\begin{abstract}
Public awareness to run shari'ah in life gives laundry entrepreneurs opportunity to open a syariah-based laundry service business. Islamic laundry service businesses have very good prospects if they use a strategy that is in line with the company. This study aims to see how the prospects and strategies carried out by Shari'ah-based laundry services in Medan. The method used in this study is a SWOT analysis. After conducting research, the Shari'a-based laundry service business has very good prospects in terms of increasing turnover, increasing the number of consumers and broad market share. Shari'ah laundry service business has the prospect of developing, therefore one of the strategies that can be done is to open a branch of the company in order to improve service, and also improve the quality and trust of consumers.
\end{abstract}

Keyword : Shari'ah Laundry, Strategy, SWOT Analysis

\begin{abstract}
Abstrak
Kesadaran masyarakat untuk menjalankan syari'ah dalam kehidupan memberi peluang kepada pengusaha laundry untuk membuka usaha jasa laundry berbasis syari'ah. Usaha jasa laundry syariah memiliki prospek yang sangat baik jika menggunakan strategi yang sesuai dengan perusahaan. Penelitian ini bertujuan untuk melihat bagaimana prospek dan strategi yang dilakukan usaha jasa laundry berbasis syari'ah di kota Medan. Metode yang digunakan dalam penelitian ini adalah analisis SWOT. Setelah dilakukan penelitian, usaha jasa laundry berbasis syari'ah memiliki prospek yang sangat baik baik dilihat dari segi peningkatan omzet, peningkatan jumlah konsumen dan pangsa pasar yang luas. Perusahaan jasa laundry syari'ah memiliki prospek untuk berkembang, untuk itu salah satu strategi yang dapat dilakukan adalah membuka cabang perusahaan dalam rangka meningkatkan pelayanan, dan juga meningkatkan kualitas dan kepercayaan konsumen.
\end{abstract}

Kata Kunci : Laundry syari’ah, Prospek, SWOT

\section{PENDAHULUAN}

Setiap manusia dianjurkan untuk menjalankan syari'ah oleh agama untuk menyempurnakan agamanya. Salah satu kegiatan yang sering disandingkan dengan syari'ah adalah perekonomian dibidang usaha, perusahaan yang disandingkan dengan syari'ah harus 


\section{4 | Analisis Prospek dan Strategi Pengembangan Usaha Jasa Syariah}

dijalankan dengan benar sesuai dengan namanya. Instrument ekonomi/ perusahaan yang tidak menjalankan perusahaan sesuai dengan syari'ah akan menjadikan "syari'ah" hanya sebagai bantalan stempel” yang ompong, bahkan justru akan mencederai nama baik Islam itu sendiri (Mustafa Kamal Rokan: 2013). Saat ini banyak terlihat suaha-usaha yang menyandingkan label syari'ah dengan perusahaannya, salah satunya adalah usaha jasa laundry. Laundry Syari'ah di kota Medan ada beberapa perusahaan di antaranya ada laundry syari dan ada laundry syariah, kedua label ini telah menjadi hak paten bagi perusahaan. Perbedaan usaha jasa laundry syar’i dengan usaha jasa lainnya terletak pada proses pencuciannya yakni usaha jasa laundry syar’i menerapkan sistem thaharah, dengan demikian produk yang dijual perusahaan laundry berbasis syari'ah ini adalah sistem thaharah dengan kualitas suci pakaian dari hadas.

Dunia usaha jasa laundry sejak tahun 2010 merupakan usaha di bidang UMKM yang sangat diminati masyarakat tercatat bahwa setiap tahunnya perusahaan laundry tumbuh sebesar 20\% per tahun yang mencakup semua daerah di Indonesia. Usaha jasa laundry berlabel syar'i hadir sejak tahun 2016, dan perusahaan ini merupakan perusahaan jasa laundry yang pertama di Medan yang menerapkan sistem syari'ah di perusahaannya.

Sejak berdirinya usaha jasa laundry syar’i sebagai usaha jasa laundry berbasis syari'ah di kota Medan, memberikan peluang kepada masyarakat untuk bisa menjalankan syari'ah dalam bidang pembersihan pakaian. Perusahaan dari tahun ke tahun mengalami peningkatan dari segi jumlah konsumen $10 \%$ - $15 \%$ perhari di tahun 2017 - 2018 sehingga total konsumen yang mereka miliki saat ini adalah \pm 900 konsumen yang berasal dari berbagai agama.

Selain konsumen, perusahaan jasa laundry syar`i juga mengalami peningkatan dalam bidang omzet. Pendapatan yang diterima pada awal pendirian seperti usaha laundry syar`i hanya mencapai 2ojuta perbulan dan di tahun 2019 usaha laundry menerima omzet hingga 8ojuta perbulannya dengan HPP 30\% untuk keuntungan dan 70\% untuk operasional. Hal ini membuktikan bahwa perusahaan jasa laundry syari memiliki daya saing dengan perusahaan laundry non-syari'ah lainnya. Setiap perusahaan yang mengalami peningkatan omzet dan mengalami keuntungan yang besar dari tahun ke tahun akan mendukung dan layak untuk berkembang di masa akan datang (Nurhalimah, et.all: 2017).

Faktor pendukung untuk mengembangkan perusahaan di bidang jasa laundry yang paling utama adalah SDM. SDM merupakan sumber daya manusia atau karyawan adalah faktor penggerak berjalannya perusahaan, karena semua hal di dalam usaha laundry syariah dilakukan oleh manusia baik dari proses pencucian hingga penyaluran kepada konsumen. Salah satu karakteristik SDM yang mampu mendorong perkembangan perusahaan adalah SDM yang memiliki kualitas sesuai dengan keahlian di bidangnya. Ciri khas sumber daya manusia yang memiliki kualitas adalah memiliki pendidikan yang lebih 
baik karena dengan pendidikan sumber daya manusia lebih cepat mengerti dan siap dalam menghadapi pertumbuhan dan perkembangan suatu perusahaan. SDM yang berpendidikan juga mampu membantu perusahaan menghadapai daya saing yang lebih tinggi (Isnaini Harahap: 2015).

Laundry syar’i telah melabelkan merknya dengan syari’ah dan telah menerapkan sistem syari'ah pada proses pencuciannya, akan tetapi satu kendala perusahaan ini untuk membuktikan perusahaannya sudah sesuai syari'ah yakni tidak adanya pengakuan dari MUI. Baik berupa label halal maupun sertifikat bagi SDMnya, sehingga hal inilah yang menjadi salah satu kelemahan bagi perusahaan ini.

Mayoritas konsumen perusahaan jasa laundry syar’i adalah Muslim yakni 80\% : 20\% artinya 80\% konsumen laundry adalah Muslim dan 20\% non-Muslim. Jika dilihat penduduk kota Medan mayoritas Muslim, hal ini memberikan peluang untuk pengusaha laundry berbasis syari'ah untuk mampu mengembangkan perusahaannya, setidaknya membuka cabang perusahaan untuk meningkatkan pelayanan dan pemasaran perusahaan. Akan tetapi hingga tahun 2018 perusahaan laundry syar’i belum mampu untuk mengembangkan perusahaan, hal ini menjadi salah satu kendala perusahaan.

Meski perusahaan ini memiliki prospek akan tetapi perusahaan ini belum mampu berkembang sebagaimana perusahaan non-syari'ah lainnya seperti Waz8 laundry, Tiara laundry dan lainnya. Hal ini lah yang menjadi dasar Peneliti untuk melakukan penelitian di usaha jasa laundry syar’i dengan judul "Analisis prospek dan strategi pengembangan usaha jasa Laundry berbasis syari'ah di Kota Medan”. Tujuan penelitian ini adalah untuk mengetahui bagaiamana sebenarnya prospek perusahaan jasa laundry berbasis syari'ah yang ada di kota Medan, dan apa strategi yang seharusnya dilakukan perusahaan untuk mengembangkan perusahaan.

\section{TINJAUAN TEORITIK}

\subsection{Prospek Pengembangan Usaha}

Setiap perusahaan akan memiliki prospek yang baik jika perusahaan tersebut memiliki standard kelayakan untuk bisa berkembang. Ada beberapa aspek yang dapat dilihat untuk menguji kelayakan suatu perusahaan, yakni (Danang Sanyoto: 2014):
a. Aspek pemasaran dan pasar.
b. Aspek prilaku konsumen.
c. Aspek sumber daya manusia.
d. Aspek manajemen operasional dan teknologi.
e. Aspek keuangan.
f. Aspek hukum. 
g. Aspek politik, ekonomi, sosial, dan lingkungan hidup, berkaitan dengan dampak yang diberikan oleh aspek masyarakat baik dari segi sosial, politik, budaya dan ekonomi serta lingkungan.

Suatu perusahaan dapat dikatakan memiliki prospek jika perusahaan tersebut memiliki ciri-ciri berikut ini (Nurhalimah, et. All: 2017, dan Nurwanita: 2015):

a. Memiliki peningkatan pada omzet/pendapatan yang secara tidak langsung dipengaruhi oleh peningkatan nilai jual produk pada perusahaan.

b. Menggunakan tekhnologi yang canggih atau yang sesuai dengan kebutuhan perusahaan dan mampu menunjang sistem produktivitas suatu perusahaan dan menciptakan produk yang berkualitas.

c. Penggunaan SDM yang tepat dan sesuai dengan keahliannya masing-masing.

Perusahaan harus memiliki SDM yang bisa bekerja sesuai dengan SOP perusahaan

\subsection{Strategi Pemasaran}

Suatu perusahaan akan dapat berkembang jika, startegi yang dilakukan sesuai dengan perusahaan yang dimiliki. Strategi pengembangan perusahaan biasanya erat kaitannya dengan strategi pemasaran baik terhadap produk, harga, tempat maupun distribusi pemasaran.

Strategi pemasaran adalah strategi bisnis, yang harus memayungi seluruh aktivitas dalam sebuah perusahaan, meliputi seluruh proses, menciptakan, menawarkan, pertukuran nilai, dari seorang produsen, atau satu perusahaan, atau perorangan, yang sesuai dengan ajaran Islam (Buchori Alma dan Donni Juni Priansa: 2016).

Adapun strategi yang dapat dilakukan untuk menunjang perkembangan perusahaan adalah:

a. Meningkatkan kualitas produk.

b. Menetapkan harga sesuai dengan kualitas produk menjadi strategi pemasaran yang paling utama.

c. Melakukan pemilihan lokasi yang strategi untuk meningkatkan penjualan produk perusahaan.

d. Promosi yakni periklan, memberikan hadiah atau diskon pada produk tertentu, melakukan publikasi atau sponsor.

\subsection{Usaha Jasa Laundry}

Binatu/penatu atau yang dikenal dengan istilah laundry adalah suatu kegiatan yang menggunakan jasa seseorang atau sekelompok orang untuk mencuci pakaian dengan menggunakan mesin cuci. Karakteristik usaha laundry yang paling 
menonjol ialah bergantung pada fasilitas air, listrik, dan kualitas mesin cuci (Imam Wahyudi Winarsih: 2010).

\section{METODE PENELITIAN}

\subsection{Jenis Penelitian}

Penelitian yang akan peneliti lakukan adalah penelitian lapangan (field research) dengan jenis penelitian kualitatif dengan metode penelitian deskriptif yaitu penelitian yang dimaksudkan untuk mengumpulkan infomasi mengenai status suatu gejala yang ada, yaitu keadaan gejala menurut apa adanya pada saat penelitian dilakukan tanpa bermaksud membuat kesimpulan yang berlaku untuk umum atau generalisasi (Fenti Hikmawati, 2018: 88). Metode deskriptif adalah membuat deskripsi, gambaran atau lukisan secara sistematis, factual dan akurat mengenai fakta-fakta, sifat-sifat serta hubungan antarfenomena yang diselidiki (Moh. Nazir: 2005).

\subsection{Teknik Pengumpulan Data}

Data dikumpulkan baik dari primer atau sekunder, peneliti menggunakan teknik sebagai berikut :

a. Wawancara adalah proses kejadian atau suatu proses interaksi antara pewawancara (interviewer) dan sumber informasi atau orang yang diwawancarai (interviewee) melalui komunikasi langsung.

b. Observasi yakni cara pengambilan data dengan menggunakan mata tanpa ada pertolongan alat standar lain untuk keperluan tersebut (Moh. Nazir, 2005: 75).

c. Dokumentasi merupakan catatan peristiwa yang sudah berlalu, baik berbentuk tulisan, gambar atau karya-karya monumental.

\subsection{Teknik Pengolahan dan Analisis Data}

Analisis data merupakan suatu proses sistematis pencarian dan pengaturan transkip wawancara, observasi, catatan lapangan, dokumen, foto, dan material lainnya untuk meningkatkan pemahaman peneliti tentang data yang telah dikumpul, sehingga memungkinkan temuan penelitian disajikan dan diinformasikan kepada orang lain (A. Muri Yusuf, 2015: 401).

Adapun analisis data yang dilakukan pada penelitian kualitatif adalah:

a. Pendekatan umum analisis data kualitatif, yaitu induktif pada awalnya, namun menjadi deduktif pada tahap selanjutnya.

b. Melakukan editing dengan cara reduksi, yaitu suatu bentuk analisis yang mempertajam, memilih, memfokuskan, membuang dan menyusun dalam suatu di mana kesimpulan akhir dapat digambarkan dan diverifikasikan. 
c. Malakukan koding (coding) dan kategoris (categorizing) terhadap data, hal ini bertujuan sebagai klarifikasi data.

d. Disaplay data atau penyajian data yang dapat dilakukan dengan membuat suatu bagan atau gambaran tentang data penelitian.

e. Melakukan penarikan kesimpulan atau verifikasi data, sebagai akhir dalam menganilis data penelitian.

\subsection{Analisis SWOT}

Analisis SWOT yaitu suatu cara untuk mengidentifikasi berbagai faktor secara sistematis dalam rangka merumuskan strategi perusahaan, analisis ini didasarkan atas logika dapat memaksimalkan kekuatan (strength) dan peluang (oppurtunities), namun secara bersamaan dapat meminimalkan kelemahan (weaknesses) dan ancaman (threats). Mengelola kinerja merupakan keharusan bagi perusahaan, karena dengan ini perusahaan dapat menggunakan seluruh poteni sumber daya yang tersedia secara optimal untuk memaksimalkan kekayaan pemilik badan usaha dan menciptakan nilai untuk stakeholder (Freddy Rangkuti: 2015).

Langkah-langkah SWOT dalam penelitian ini dapat dilakukan dengan (Freddy Rangkuti: 2011):

a. Persiapan: Menyamakan Pemahaman

b. Mengidentifikasi Faktor Internal dan Eksternal

c. Membuat matriks evaluasi faktor internal dan eksternal

d. Membuat matriks posisi perusahaan

\section{HASIL DAN PEMBAHASAN}

4.1 Keuntungan penjualan produk pada usaha jasa laundry berbasis syari'ah

Salah satu tujuan usaha jasa laundry syar’i adalah mendapatkan keuntungan yang layak sebagai faktor berkembangnya usaha tersebut. Sejak berhijrah dari konsep konvensional di tahun 2016, usaha ini mengalami peningkatan dalam bidang keuntungan dan penjualan jasa. Sebagaimana yang dipaparkan dalam tabel berikut ini:

Tabel 4.1

Rekapitulasi penjualan dan omzet pendapat

\begin{tabular}{|c|c|c|c|c|}
\hline Tahun & Total Produksi & Total Pendapatan & Biaya Operasinal & $\begin{array}{c}\text { Total } \\
\text { Keuntungan }\end{array}$ \\
\hline 2017 & 14.152 & Rp 200.565.000 & Rp. 140.395.500 & Rp. 60.169.500 \\
\hline 2018 & 18.985 & Rp 241.740.000 & Rp. 169.218.000 & Rp. 72.522.000 \\
\hline total & 33.137 & Rp. 442.305.000 & Rp. 309.613.500 & RP. 132.691.500 \\
\hline
\end{tabular}


Tahun 2017 perusahaan laundry syar’i menerima jasa pencucian sebesar 14.152 dengan $8.885 \mathrm{~kg}$ produk kiloan dan 5.267 pcs produk satuan menyumbangkan pendapatan sebesar Rp. 200.565.000,-. Sedangkan di tahun 2018 perusahaan laundry syar’i menerima jasa atau menjual jasa sebesar 18.985 dengan $10.775 \mathrm{~kg}$ produk kiloan dan 8.210 pes produk satuan dan menyumbangkan pendapatan sebesar Rp. 241.740.000.

Berdasarkan pemaparan tersebut dapat terlihat jelas bahwa baik dari sistem panjualan maupun pendapatan perusahaan laundry syar’i mengalami peningkatan. Pendapatan yang diterima perusahaan lebih besar daripada biaya operasional (TR> TC). Berdasarkan data ini dapat disimpulka bahwa perusahaan ini memiliki kelayakan untuk berkembang.

\subsection{Prospek dan pengembangan usha jasa laundry syar' $i$ sebagai bisnis syari'ah}

Penelitian ini meneliti prospek dan strategi pengembangan usaha jasa laundry syar’i yang berlokasi di kota Medan. Setelah dilakukan penelitian perusahaan ini memiliki prospek yang baik. Sedangkan untuk menentukan strategi yang sesuai Peneliti menggunakan SWOT yakni melihata kekuatan, kelemahan, peluang dan ancaman yang ada di perusahaan tersebut. Adapun langkah-langkahnya adalah:

a. Persiapan: Menyamakan Pemahaman

Langkah ini dilakukan bertujuan untuk mengidentifikasi peluang dan ancaman yang dihadapi serta kekuatan dan kelemahan yang dimiliki perusahaan laundry berbasis syari'ah melalui penelaahan terhadap lingkungan usaha dan potensi sumber daya organisasi dalam menetapkan sasaran dan merumuskan strategi organisasi yang realistis dalam mewujudkan visi dan misinya.

b. Mengidentifikasi Faktor Internal dan Eksternal

Perusahaan laundry syari memiliki prospek untuk berkembang dapat dilihat dari faktor internal dan eksternal perusahaan, adapun faktor internal perusahaan laundry syari diklarifikasi pada 2 kategori sebagai berikut:

1) Kekuatan

a) Memiliki inovasi baru yang tidak diterapkan pada perusahaan laundry lainnya. Adapun inovasi yang telah diterapkan perusahaan adalah proses pencucian yakni dengan sistem thaharah. Sistem thaharah ini adalah inovasi baru yang dilakukan perusahaan dan belum dimiliki perusahaan non-syari'ah lainnya. 
b) Adanya kerja sama antar perusahaan dengan lembaga-lembaga agamais. Kekuatan perusahaan lainnya adalah menjalin kerja sama dengan lembagalembaga agamais yang dapat mendukung perkembangan perusahaan.

c) Memiliki SDM yang sesuai dengan keahlian di bidangnya sehingga memberikan kualitas yang sesuai dengan brand perusahaan.

d) Pasca hijrah menjadi laundry syar’i di tahun 2016 perusahaan ini mampu meningkatan omzet dan keuntungan sehingga di tahun terakhir perusahaan ini mampu mencapai keuntungan bersih sebesar Rp. 72.000.00o,' lebih tinggi dibandingkan tahun sebelumnya. Setiap tahunnya perusahaan ini mengalami peningkatan dalam bidang omzet sebesar $20 \%$.

2) Kelemahan

a) Perusahaan laundry syar’i tidak menyediakan sistem delivery. Namun bagi konsumen yang memerlukan jasa delivery pihak perusahaan bekerja sama dengan ojek online, akan tetapi biaya delivery tersebut dibebankan kepada konsumen dan tidak terhitung sebagai jasa pencucian.

b) Tidak adanya label halal atau pengakuan halal dari pihak MUI baik dari segi pemakaian bahan baku maupun proses pencucian yang diyakini sebagai syar'i..

c) Penggunaan tekhnologi masih kurang canggih, karena berdasarkan wawancara Peneliti dengan owner masih banyak alat tekhnologi yang digunakan perusahaan masih memerlukan upgrade.

Sedangkan untuk faktor eksternal perusahaan laundry syar’i adalah:

1) Peluang

a) Pasca terjadinya gerakan 212 yang memberikan dampak positif terhadap masyarakat untuk bergerak lebih dekat kepada syari'ah. Hal ini memberikan dukungan positif sekaligus memberikan peluang yang sangat baik terhadap perkembangan perusahaan laundry berbasi syari'ah yang ada di Indonesia umumnya.

b) Penduduk masyarakat Medan mayoritas adalah Muslim, ini menjadi salah satu peluang bagi perusahaan untuk bisa mengembangkan perusahaan.

2) Ancaman

a) Konsumen yang sering tidak mengambil pakaiannya hinga tahunan hal ini menimbulkan kerugian perusahaan.

b) Munculnya pesaing baru, akibat proses pencucian dan kualitas yang diberikan perusahaan laundry syar'i ini bisa diterapkan diperusahaan laundry manapun dan bisa mengakibatkan munculnya perusahaan- 
perusahaan laundry dengan proses pencucian yang sama dan harga yang terjangkau.

c. Membuat matriks evaluasi faktor internal dan eksternal.

Hasil identifikasi faktor-faktor internal yang merupakan kekuatan dan kelemahan akan dipindahkan ke tabel matriks evaluasi faktor internal (EFI) dan akan diberikan pembobotan rating dan skor. Faktor eksternal yang merupakan peluang dan ancaman akan dimasukkan juga ke tabel matriks evaluasi faktor eksternal (EFE) dan akan diberikan skor, bobot dan rating. Kemudian kedua faktor tersebut dijumlahkan untuk mencari skor mana yang lebih tinggi.

Di bawah ini merupakan tabel perhitungan pembobotan dikalikan rating dari faktor -faktor internal:

Tabel 4.2

Matriks Evalution Factor Internal

\begin{tabular}{|l|l|c|c|c|}
\hline No & Strength & Rating & Bobot & Skor \\
\hline $\mathbf{1}$ & Memiliki inovasi baru & 4 & 0,17 & 0,68 \\
\hline 2 & $\begin{array}{l}\text { Kerja sama dengan lembaga } \\
\text { keagamaan }\end{array}$ & 3 & 0,16 & 0,48 \\
\hline 3 & Keuntungan terus bertambah & 3 & 0,17 & 0,51 \\
\hline 4 & $\begin{array}{l}\text { SDM yang memiliki keahlian di } \\
\text { bidangnya }\end{array}$ & 2 & 0,20 & 0,40 \\
\hline & Total Kekuatan & & $\mathbf{0 , 7}$ & $\mathbf{2 , 0 7}$ \\
\hline & Weakness & Rating & Bobot & skor \\
\hline 1 & Tidak adanya delivery & 3 & 0,19 & 0,57 \\
\hline 2 & Label halal & 3 & 0,21 & 0,63 \\
\hline 3 & Tekhnologi yang belum canggih & 2 & 0,16 & 0,32 \\
\hline & Total Kelemahan & 0,56 & $\mathbf{1 , 5 2}$ \\
\hline & Selisih Total Kekuatan - Total Kelemahan $=2,07-1,52=\mathbf{0 , 5 5}$ \\
\hline
\end{tabular}

Berdasarkan tabel tersebut diketahui bahwa total skor kekuatan lebih besar dibandingkan total skor kelemahan yakni 2,07 > 1,52 dengan selisih perbedaan 0,55. Hal ini membuktikan usaha laundry syar’i memiliki faktor internal yakni kekuatan yang dapat mendukung perkembangan perusahaan laundry. 
Tabel 4.3

Matriks Evalution Factor Eksternal

\begin{tabular}{|c|c|c|c|c|}
\hline No & Opportunity & Rating & Bobot & Total \\
\hline 1 & Adanya gerakan pasca 212 & 3 & 0,19 & 0,57 \\
\hline 2 & Mayoritas masyarakat Muslim & 3 & 0,21 & 0,63 \\
\hline & Total Peluang & & 0,4 & $\mathbf{1 , 2}$ \\
\hline & Treath & Rating & Bobot & Total \\
\hline 1 & Munculnya pesaing baru & 3 & 0,22 & 0,66 \\
\hline 2 & $\begin{array}{l}\text { Konsumen yang tidak } \\
\text { mengambil pakaian }\end{array}$ & 2 & 0,15 & 0,30 \\
\hline & Total Tantangan & & 0,37 & $\mathbf{0 , 9 0}$ \\
\hline
\end{tabular}

Jika dihitung selisih antara faktor interla dengan faktor eksternal yakni o,55 $0,24=0,31$. Keadaan ini menunjukkan bahwa faktor internal lebih berpengerauh dan mendukung dibandingkan faktor esternal.

d. Membuat matriks posisi perusahaan

Berdasarkan hasil evasluasi faktor eksternal dan internal di atas, selanjutnya dibuat matrik posisi perusahaan yang bertujuan untuk mengetahui posisi kuadran perusahaan. Berdasarkan tabel tersebut juga dapat diketahui bahwa faktor internal lebih besar dibandingkan faktor eksternal perusahaan. Adapun matriks perusahaan laundry syar’i adalah sebagai berikut:

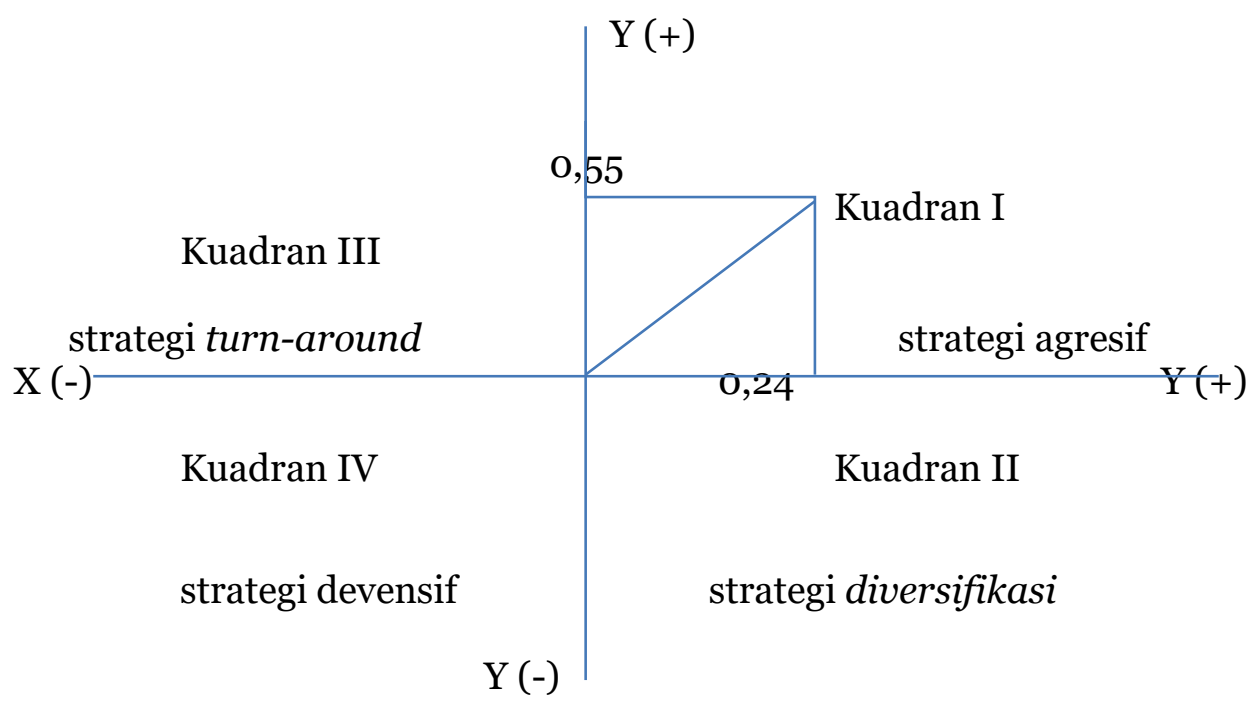

Gambar 4.1

Matriks Posisi Perusahaan

Berdasarkan matriks tersebut di atas posisi perusahaan laundry syar’i berada pada posisi kuadran I yang menunjukkan bahwa posisi perusahaan berada pada posisi yang kuat dan posisi yang mampu memanfaatkan kekuatan dan peluang yang ada. Selain itu, posisi ini juga merupakan posisi yang mendukung strategi agresif yang didesain untuk mendukung perkembangan perusahaan dengan memanfaatkan 
kekuatan dan peluang perusahaan. Pemanfaat kekuatan untuk strategi agresif dapat mengembangkan inovasi atau karakteristik perusahaan dan mengutamakan kualitas yang lebih baik, hal ini juga dapat mendukung peningkatan penjualan jasa sehingga perusahaan mendapatkan keuntungan yang lebih tinggi. Sedangkan pemanfaatan peluang, perusahaan harus memanfaatkan terjadinya pergeseran nilai yang semakin tinggi dengan memperluas pemasaran.

e. Tahap Penentuan alternatif strategi

Setelah diketahui posisi perusahaan, maka akan ditentukan beberapa alternative strategi yang dapat dilakukan perusahaan laundry syar’i untuk berkembang. Pada dasarnya untuk menentukan berbagai alternative tersebut dapat dilakukan dengan berbagai cara salah satunya adalah berdasarkan analisis SWOT berikut ini. Matriks SWOT telah menjelaskan bahwa strategi yang harus dilakukan oleh perusahaan laundry syari adalah strategi agresif yakni menguatkan faktor kekuatan dan memanfaat semua faktor peluang yang mampu mendukung perusahaan.

Berdasarkan matriks tersebut juga perusahaan laundry syar’i dapat menyususn strategi dengan mengidentifikasi antar faktor internal dan faktor eksternal yakni SO, WO, ST dan WT sebagaimana yang dijelaskan berikut ini:

1) SO yakni memaksimalkan kekuatan perusahaan dan memanfaatkan peluang yang ada, dengan cara:

a) Meningkatkan inovasi pada perusahaan baik pada produk maupun pada penetapan harga sehingga dengan inovasi tersebut perusahaan mampu meningkatkan penjualan dan meningkatkan jumlah konsumen sebagai faktor utama yang mampu mendukung pertumbuhan dan perkembangan perusahaan.

b) Melakukan pemasaran yang lebih baik dan memperluas kerja sama dengan berbagai lembaga-lembaga dan jaga terhadap masyarakat Muslim menyeluruh.

c) Menjaga SDM yang di miliki dengan meningkatkan keterampilan di bidangnya masing-masing sehingga menghasilkan produksi yang memiliki kualitas yang lebih baik.

2) WO yakni meminimalkan kelemahan dengan memanfaatkan peluang, dengan cara:

a) Perusahaan harus berupaya untuk mendapatkan label halal pada bahan baku yang digunakan dan mendapatkan sertifikat halal untuk proses pencucian yakni thaharah. Dengan label halal dan sertifikat tersebut para masyarakat yakni bahwa perusahaan ini benar-benar sesuai syar’i dan bukan hanya 
menggunakan brand syar'i akan tetapi ternyata tidak ada pernyataan bahwa perusahaan tersebut syar'i dari MUI.

b) Menerapkan sistem delivery sebagaimana yang ada pada perusahaan laundry syar’i hal ini untuk meningkatkan pelayanan terhadap konsumen.

c) Meningkatkan kualitas tekhnologi sehingga menghasilkan produk yang bersih, nyaman dan berkualitas tinggi. Sehingga dengan strategi ini dapat mendukung peningkatan penjualan.

3) ST yakni memaksimalkan kekuatan dari berbagai ancaman dari luar perusahaan, dengan cara:

a) Mengembangkan inovasi baru dan menguasi pangsa pasar khususnya pangsa pasar Muslim dan menerapkan harga yang lebih terjangkau sehingga jika muncul pesaing baru perusahaan laundry syar’i tetap menjadi pilihan alternative bagi konsumen.

b) Kualitas merupakan salah satu yang harus dipertahankan dan bahkan ditingkatkan karena kualitas merupakan salah satu faktor daya tarik konsumen untuk tetap bertahan, dan ini juga menjadi daya saing yang dapat dilakukan untuk menghadapi perusahaan baru.

4) WT yakni meminimalkan kelemahan dari berbagai ancaman yang datang, dengan cara:

a) Meningkatkan kualitas meskipun masih menggunakan tekhnologi yang belum canggih dan masih memerlukan upgrade perusahaan laundry harus mampu menjaga kepercayaan konsumen dan memberikan kualitas yang lebih baik, sehingga perusahaan mampu menghadapi persaingan yang lebih baik. Karena usaha dalam bidang jasa laundry kualitas adalah faktor utama yang diperhatikan setiap konsumen.

b) Menghadirkan sistem delivery pada perusahaan secara gratis, ini dilakukan untuk meminimalisir penumpukan pakaian dan mengurangi keterlambatan pengambilan hasil produksi. Kehadiran delivery bagi perusahaan akan membantu pertumbuhan perusahaan dan meningkatkan pendapatan.

Berdasarkan alternative-alternative strategi perusahaan laundry syar’i tersebut di atas posisi perusahaan laundry syar’i memiliki posisi yang sangat menguntungkan dan posisi yang memiliki prospek untuk dikembangkan. Terutama pada strategi yang memaksimalkan dan memanfaatkan kekuatan, meminimalkan kelemahan dan mengatasi ancaman, karena kekuatan merupakan faktor yang sangat mendukung perkembangan perusahaan. 
Dari analisis SWOT tersebut maka perusahaan laundry syar’i dapat menggunakan strategi-strategi tersebut untuk mengembangkan perusahaan sebagaimana yang dirangkum dalam matriks berikut ini:

Tabel 4. 4

\section{Matriks Alternatif Strategi}

\begin{tabular}{|c|c|c|}
\hline \multirow[b]{2}{*}{ Eksternal } & Strengths ( Kekuatan) & Weakness(kelemahan) \\
\hline & $\begin{array}{l}\text { 1. Memiliki inovasi baru } \\
\text { 2. Kerja sama dengan berbagai } \\
\text { lembaga keagamaan } \\
\text { 3. Meningkatnya keuntungan } \\
\text { 4. Memiliki SDM sesuai dengan } \\
\text { bidangnya }\end{array}$ & $\begin{array}{l}\text { 1. Tidak ada sistem delivery } \\
\text { 2. tidak ada sertifikat dan } \\
\text { label halal dari MUI } \\
\text { 3. Penggunaan tekhnologi } \\
\text { yang belum canggih }\end{array}$ \\
\hline Peluang(Oppurtunity) & Strategi SO & Strategi WO \\
\hline $\begin{array}{l}\text { 1. Adanya pergerakan } \\
\text { hijrah pasca } 212 \\
\text { 2. Mayoritas } \\
\text { penduduk } \\
\text { 3. Fasilitas yang } \\
\text { cukup }\end{array}$ & $\begin{array}{l}\text { 1. } \begin{array}{l}\text { Meningkatkan inovasi pada } \\
\text { perusahaa sebagai salah satu } \\
\text { upaya untuk meningkatkan }\end{array} \\
\text { penjualan } \\
\text { 2. Meningkatkan mutu SDM } \\
\text { sebagai salah satu fasilitas } \\
\text { pelayanan } \\
\text { 3. } \begin{array}{l}\text { Memperluas kerjasama baik } \\
\text { lembaga maupun terhadap } \\
\text { masyarakat umum }\end{array}\end{array}$ & $\begin{array}{l}\text { 1. Perusahaan harus lebih } \\
\text { ambisius untuk } \\
\text { memperoleh label halal } \\
\text { dan sertifikat halal dari } \\
\text { MUI } \\
\text { 2. Menerapkan sistem } \\
\text { delivery untuk } \\
\text { meningkatkan } \\
\text { pelayanan } \\
\text { 3. Meningkatkan } \\
\text { tekhnologi baik dari } \\
\text { mesin cuci maupun } \\
\text { aplikasi perusahaan }\end{array}$ \\
\hline Treath (Ancaman) & Strategi ST & Strategi WT \\
\hline $\begin{array}{l}\text { 1. Penetapan harga } \\
\text { 2. Pengambilan } \\
\text { pakaian yang tidak } \\
\text { tepat }\end{array}$ & $\begin{array}{l}\text { 1. Meningkatkan inovasi produk } \\
\text { baik yang sudah ada atau } \\
\text { menciptakan produk lain } \\
\text { untuk memperkuat } \\
\text { perusahaan dari para pesaing } \\
\text { 2. Meningkatkan kualitas yang } \\
\text { lebih baik sehingga } \\
\text { perusahaan tetap menjadi } \\
\text { pilihan alternative } \\
\text { 3. Menstabilkan harga dengan } \\
\text { HPP perusahaan untuk } \\
\text { meningkatkan keuntungan }\end{array}$ & $\begin{array}{l}\text { 1. Menggunakan tekhnologi } \\
\text { yang lebih canggih yang } \\
\text { mampu meminimalkan } \\
\text { limbah } \\
\text { 2. Memperluas kerjasama } \\
\text { dan memasuki ranah } \\
\text { pemerintahan untuk } \\
\text { mendapatkan dukungan } \\
\text { dari pemerintah } \\
\text { terutama mendapatkan } \\
\text { label halal }\end{array}$ \\
\hline
\end{tabular}

Berdasarkan tabel di atas dapat diketahaui bahwa usaha jasa laundry berbasis syari'ah yang berada di kota Medan memiliki kekuatan dan kelemahan sebagai faktor internal perusahaan sedangkan peluang dan ancaman adalah faktor eksternal perusahaan. Strategi SWOT yang dilakukan dapat memberikan strategi bagi pengusaha untuk mengembangkan perusahaan yakni dengan menggunakan kekuatan untuk memanfaatkan peluang, meminimalkan kelemahan dengan memanfaatkan 
peluang yang ada, menggunakan kekuatan untuk mengatasi ancaman yang datang dari luar dan meminimalkan kelemahan agar dapat mengatasi ancaman dari pesaingpesaing yang bisa saja hadir di masa akan datang.

\section{KESIMPULAN}

Berdasarkan hasil penelitian yang telah dilakukan Peneliti, dapat ditarik beberapa kesimpulan, bahwa usaha jasa laundry berbasis syari'ah yang berlokasi dikota Medan memiliki prospek yang sangat baik untuk berkembang, hal ini dapat terlihat dari peningkatan omzet mereka dari tahun ke tahun, begitu juga dengan jumlah konsumen yang terus bertambah. Usaha jasa laundry syari juga memiliki SDM yang berkualitas sesuai dengan keahliannya. Strategi yang dapat dilakukan untuk mendorong perkembangan perusahaan berdasarkan analisis SWOT yang telah dilakukan adalah meningkatkan mutu atau inovasi perusahaan, memperluas jaringan pemasaran dan juga menyediakan fasilitas yang lebih baik untuk kenyamana dan kepuasan konsumen.

\section{DAFTAR PUSTAKA :}

\section{Daftar Buku :}

Alma, Buchari dan Donni Juni Priansa. 2016. Manajemen Bisnis Syariah, Bandung: Alfabeta.

Harahap, Isnaini. 2015. Analisis Dampak Penerapan Perbankan Syariah terhadap Sektor UMKM, Disertasi: UINSU.

Hikmawati, Fenti. 2018. Metodologi Penelitian, Depok: Rajawali Pers.

Nazir, Moh. 2005. Metode Penelitian, Bogor: Ghalia Indonesia.

Rangkuti, Feddy. 2015. SWOT Balance Scorecard, Jakarta: Gramedia Pustaka. Pustaka.

Rokan, Mustafa Kamal. 2013. Bisnis ala Nabi Teladan Rasulullah Saw dalam Berbisnis, Yogyakarta: Bentang Pustaka.

Sunyoto, Danang. 2014. Studi kelayakan Bisnis, Yogyakarta: Caps.

Winaris, Imam Wahyudi. 2010. Jos Kaya dari Bisnis Laundry Kiloan, Jogjakarta: FlashBokks.

Yusuf, A. Muri. 2015. Metode Penelitian kuantitatif, kualitatif dan penelitian gabungan, Jakarta: Kencana.

\section{Daftar Jurnal :}


Lubis, Nurhalimah, et.al, Prospek Pengembangan Industri Pengelolaan Salak dalam Membangun Ekonomi Masyarakat menurut Perspektif Ekonomi Islam (Studi Kasus Desa Parsalakan Kec. Angkola Barat Kab. Tapsel), Jurnal Fitrah ol. o3 No. o2 Desember 2017.

Wanita, Nur, Perkembangan Usaha Mikro, Kecil dan Menengah (UMKM) di Pasar Manonda Palu, Jurnal Istiqra, Vol. o3 No. 02, 2015. 